\title{
1 \\ The Privatisation of Australian Corporate Law
}

\section{Ross Grantham ${ }^{1}$}

Anyone looking at the Corporations Act 2001 (Cth) would be justified in thinking that company law in Australia was both wholly statutory and an instrument of public regulation. Although Anglo-Australian company law may have originally grown out of the law of partnership and been built, largely by the courts, from the material of the private law, the growth over the last 30 years in the complexity, range of matters covered and sheer volume of the Corporations Act would seem to confirm the intuition that Australia's company law is now both statutory and public. However, while there is no denying the shift in the source of company law, the particular form corporate regulation now takes is actually making Australian company law more, rather than less, private.

This trend has at least two important implications for the future of Australian company law and the Corporations Act in particular. First, the primary audience of the law must now be understood to be those who are involved in the operation of companies - business people rather than lawyers and the courts. If that is the case, then the form, language and complexity of the Corporations Act seems wholly ill-suited to that task. Second, privatisation brings to the fore the issues of the legitimacy of corporate power, and the purposes for which as a matter of policy we

1 Professor of Commercial Law, T C Beirne School of Law, University of Queensland. 
should recognise the corporate form. These two factors combine to suggest that the Corporations Act is no longer fit for purpose and must be reformed and reconceived from the ground up.

\section{The Privatisation of Australian Company Law}

The privatisation of company law is, in large measure, a consequence of a 'proceduralised' approach to regulation. ${ }^{2}$ Broadly, this means that instead of directly prescribing the policy goals or desired outcomes, the legislature seeks to achieve the substantive policy goals by creating a self-balancing system that creates and relies upon incentives designed to induce those being regulated to bring about the desired conduct or outcomes. The policy goals remain public-regarding, but the mechanisms no longer rely on a direct prescription backed by sanctions and imposed by external regulators such as the courts. Instead, the mechanisms now used to implement corporate regulation focus on the process of decision-making and the creation of largely internal governance procedures as the means of regulating the behaviour of the participants in the corporate enterprise.

By prescribing the way in which a company might achieve its goals through restructuring its decision-making processes such that the 'right' people are involved and that the decision-making process itself is conducted in a way that is permeable to the state's social-economic policies - the overall regulatory goals for the company are achieved. Thus, corporate regulation increasingly reflects an ideal model of decision-making that embodies the essential features of procedural correctness. These features are broadly that the decision-makers are impartial, that they are informed, and that the decision is rational or reasonable.

Evidence of proceduralisation may now be found in most parts of the Corporations Act, but two examples will suffice. ${ }^{3}$ One example is the procedure established to deal with directors' conflicts of interest. Traditionally, this was dealt with by a common law rule which prohibited a director from acting while conflicted and was enforced by claims brought

2 J Black, 'Proceduralizing Regulation: Part I' (2000) 20 Oxford Journal of Legal Studies 597 and 'Proceduralizing Regulation: Part II' (2001) 21 Oxford Journal of Legal Studies 33.

3 The case for a proceduralised approach now being a defining characteristic of Australian company law is made fully in R Grantham, 'The Proceduralisation of Australian Corporate Law' (2015) 43 Federal Law Review 233. 
in the courts by those aggrieved by a breach of the rule. The solution to this issue that is now found in ss 191 to 196 of the Corporations Act requires that a conflicted director disclose the conflict, in a prescribed form, to designated groups. The procedure vests in those designated groups power to approve the conflicted director's continuing involvement and to validate tainted transactions, and then provides an escape valve through a delegation to ASIC to make exemptions.

A second example is in relation to changes to the company's capital structure - reductions in capital, companies buying their own shares, and providing financial assistance. Historically, there was an absolute prohibition on such activity. The law then moved to allow such changes with external regulatory supervision (court approval). Now we have a situation where the regulatory approval is given by shareholders. The likely incentives of the shareholders are such that their approval (or not) will secure the underlying policy goals.

The important consequence for present purposes is that whether by design or consequence, a proceduralised approach is making company law more, rather than less, private. The use of internal governance procedures to address many of the perennial issues of company law, in place of external supervision by regulators or the courts, is making company law an increasingly self-executing, enclosed system. The state may have prescribed how things must be done, but the application of these processes is increasingly vested in the participants in the corporate enterprise.

The second and closely related factor contributing to privatisation is the sharp decline in recent decades in the volume, and type, of matters reaching the courts. Some sense of the magnitude of the change is provided by a survey of the cases reported in Australia's two specialist sets of corporate law reports. ${ }^{4}$ In the period from 1991, before the reforms of the Corporate Law Simplification Program and Corporate Law Economic Reform Program were introduced, to 2013, there was a decline in the number of cases being reported of 37 per cent. The change is even more marked when one focuses on core company law issues - matters that define and reflect the essential characteristics of the corporate form and the minimum content of corporate law - where the rate of decline in cases is well over 50 per cent in the same period.

4 See Grantham, n 3 above. 
It is also clear from this survey that the role of the court has changed. Whereas in 1991 the majority of cases saw the courts fulfilling the traditional judicial role of interpreting statutory provisions and corporate constitutions, and applying common law doctrines, to determine the rights and duties of the litigants, by 2013 the courts were hearing only a handful of core corporate law issues and in the vast majority of those the court's role was merely a regulatory one of supervising a decision-making process prescribed by the Corporations Act or the company's constitution.

Whether the decline in court cases is a consequence of proceduralisation or part of the worldwide decline in civil litigation in favour of private dispute resolution, ${ }^{5}$ the result is that issues and practices that would hitherto have been aired publicly in court are now dealt with within the company behind closed doors. While it is true that there are now more cases of directors' personal liability, it is important to recognise that the basis of liability is not the substance of corporate decisions but rather how the directors went about making the decision. The directors of James Hardie were not held liable for abandoning the victims of asbestos, but for the way in which they announced this to the market. Where previously litigation between private disputants brought issues of substance about what companies were doing into the public forum, this is no longer the case.

\section{The Implications of Privatisation}

The somewhat paradoxical effect of the regulatory approach leading to a privatisation of company law has many potential implications. Two merit comment.

\section{A. The manner and form of the Corporations Act}

An important implication of privatisation concerns the manner and form of Australian company law and the Corporations Act in particular. If the intention is to internalise much of the regulation of the company within the company's own governance structures - where the focus of the legislation is to set out the processes and procedures those involved in the corporate enterprise must follow - then the question arises as to whom the Act

5 See H Genn, Judging Civil Justice (Hamlyn Lectures 2008, CUP, 2009) Ch 2. 
is primarily addressed. Historically, all legislation, including companies legislation, was addressed to lawyers and the courts. The language of legislation, its layout, its presuppositions as to background knowledge and context, and even its accessibility, were all tailored by and for lawyers. If, however, the intention now is to directly address those involved in the corporate enterprise - to set out what they must do and how they must do it - then the Corporations Act seems ill-suited to that role. Some idea of what a user-oriented corporate statute would look like can be had by looking at the companies legislation of Canada and New Zealand: it is concise, principles-based and expressed in genuinely plain language.

In contrast, to use Cally Jordan's phrase, the Corporations Act is 'unlovely and unloved'. ${ }^{6}$ It is extraordinarily dense, complex, unclear, poorly organised and, in many respects, rather outdated. At over 2,600 substantive sections, few people if any can claim to know the Act in its entirety. Although the Simplification program in the 1990s tried to 'make it capable of being understood so that users can act on their rights and carry out their responsibilities, ${ }^{7}$ the large number of amendments made to the Act over the years has effectively deprived it of any rational or conceptual organisation - any statute that needs sections numbered to four capital letters has a problem. ${ }^{8}$ The result is that as a user guide or statement of first recourse for those involved in the corporate enterprise, the Act may as well be written Sanskrit. ${ }^{9}$ What is needed, therefore, is a root and branch review and rewriting of the Act. This endeavour, however, faces a number of significant challenges.

First, there will be an understandable reluctance to reopen the constitutional settlement underpinning the Act. The gestation of the federal legislation was long and painful and it may be thought better not to reopen old wounds. On the other hand, however, there may be advantages in reassessing the merits of federal corporate legislation. Although the advantages of federalising company law were presented during the federal takeover of corporate law in the 1990s as being

6 C Jordan, 'Unlovely and Unloved: Corporate Law Reform's Progeny' (2009) 33 Melbourne University Law Review 626.

7 Corporations Law Simplification Program, Task Force - Plan of Action (Attorney-General's Department, December 1993) 1.

8 Section 601SCAA, Corporations Act 2001 (Cth).

9 The inaccessibility of the Act may in part explain the rise of 'soft law' guides and codes of best practice. 
obvious, ${ }^{10}$ there were in fact other models and what is arguably the most successful corporate economy, the US, has a state-based model with significant, productive diversity. One of the insights of the Public Choice theory is that law is a product and that there is a market for this product. ${ }^{11}$ The federalisation of corporate law created in substance a single supplier of corporate law (the Commonwealth Parliament) and thus an effective monopoly for the supply of company law in Australia, with all of the downsides entailed by such monopolies. ${ }^{12}$

Second, Australian company law is a one-size-fits-all model. This builds complexity into the law as it seeks to carve out exceptions to adapt a model originally designed to meet the needs of large-scale enterprises in the $19^{\text {th }}$ century to micro-firms and small family businesses in the $21^{\text {st }}$ century. Again, this is not the only model. Most notably, both Europe and the US have created a range of special purpose entities tailored to the specific needs of the business or activity. ${ }^{13}$ If the ultimate aim of Australian company law is to provide an efficient and simple vehicle to conduct business, then Australia must at least consider more tailored structures.

Third, and perhaps most importantly, any reform of the Corporations Act to make it more user-friendly faces the challenge presented by Australia's current predilection for large, highly prescriptive and prolix legislation. Whatever the reasons for the explosion in legislation in the $1980 \mathrm{~s},{ }^{14}$ and the prescriptive drafting style now in vogue, this approach clearly stands in the way of Australia adopting the sort of plain-language, principlesbased, user-oriented companies legislation adopted by the likes of New

10 M Whincop, 'The Political Economy of Corporate Law Reform in Australia' (1999) 27 Federal Law Review 77.

11 Generally, see G Tullock, 'Public Choice' in S Durlauf and L Blume (eds), The New Palgrave Dictionary of Economics (London, Palgrave Macmillan, $2^{\text {nd }}$ edn, 1987).

12 A monopolistic market is one characterised by barriers to entry to the market by other suppliers, the imposition of higher prices, a reduction in consumer surplus and a limiting of consumer choice. In relation to corporate law in Australia, see Whincop (n 10) and I Ramsay, 'Company Law and the Economics of Federalism' (1990) 19 Federal Law Review 169.

13 In the US, for example, the Limited Liability Company (LLC) is a vehicle tailored to the specific needs of small businesses and quasi-partnerships, while the Professional Limited Liability Company (PLLC) is a vehicle tailored to the needs of those conducting a profession, such as medical services. A 'benefit corporation' is a particular type of for-profit entity but which includes in its defined goals consideration of social and environmental impact. Europe has always provided for quite separate forms for closely held companies and publicly held companies (designated in Germany, for example, as ' $\mathrm{GmbH}$ ' and 'AG' respectively).

14 C Berg, Policy without Parliament: The Growth of Regulation in Australia (Institute of Public Affairs, IPA Backgrounder, November 2007, Vol 19/3) 3. Berg's analysis shows a sudden and massive leap in legislative production starting in the late 1980s. 
Zealand and Canada. However, if the primary audience of company law in Australia is to be those involved in the corporate enterprise, then the expression and accessibility of the law must be massively simplified.

\section{B. Privatisation and the legitimacy of the corporate form}

The second fundamental implication of the privatising trend in Australia relates to the legitimacy of the corporate form and its social and economic power. Companies have always been repositories of wealth and power and it is a fundamental premise of modern Western liberal society that power must be legitimated. ${ }^{15}$ Where that power is subject to public oversight and control, corporate power is legitimated on fundamentally the same basis as the power of the state. However, to the extent that companies are or have become more private, questions arise as to whether, and how, the aggregation of economic, political, social and cultural power in the hands of ostensibly private entities that are legally accountable to only a small group of shareholders and in practice are accountable to no one may be justified.

This is obviously a deep and complex issue that cannot be addressed properly here. However, it is worth noting that changes over the last 20 years in the nature of corporate power have changed how this question must be understood. ${ }^{16}$ Historically, the most widely accepted basis of legitimacy of corporate power was the instrumental value of the company as a creator of wealth. The efficient utilisation of scarce resources and the maximisation of the wealth of society is a good thing, both as a means to other substantive goals and as an end in itself. The pursuit of the maximisation of social wealth is, therefore, in the public interest and, being in the public interest, serves to legitimate those institutions that bring about that goal. The modern company has proven itself to be a highly efficient means of producing wealth and, although it is not perfect and the power that is inevitably vested in the company may generate costs, those costs are more than justified by the gains. Thus, the power that arises from placing the means of production in private hands is legitimated by its superiority in maximising social wealth.

$15 \mathrm{~J}$ W Hurst, The Legitimacy of the Business Corporation (Charlottesville, University Press of Virginia, 1970) 58.

16 See R Grantham, 'The Legitimacy of the Company as a Source of (Private) Power' in K Barker et al (eds), Private Law and Power (Oxford, Hart, 2016) Ch 10. 
The real difficulty now, however, lies in the rising social and cultural power of the company. The last 20 years have seen the rise of social media, social networking, and 'Big Data', and the ability of companies such as Google, Facebook, Apple, and Microsoft to shape our social interactions, what we know of the world, and even our identities as individuals. ${ }^{17}$ As Richards and King have said:

With even the most basic access to a combination of big data pools like phone records, surfing history, buying history, social networking posts, and others, 'I am' and 'I like' risk becoming 'you are' and 'you will like.' Every Google user is already influenced by big-data-fed feedback loops from Google's tailored search results, which risk producing individual and collective echo chambers of thought. ${ }^{18}$

In respect of the costs arising from this social and cultural power, the argument for the legitimacy of the company as a generator of material wealth simply does not hold. The benefits to society of the survival of a small town or the rural way of life, or the reduction in greenhouse gas emissions, or the right of the individual to be forgotten, ${ }^{19}$ and the increases in profitability of moving a major source of employment off-shore or the invasion of our privacy to more precisely target marketing, seem to be expressed in fundamentally different currencies. The increase in one cannot bear upon or make up for losses in the other. Therefore, while as a purely economic institution the company's preeminent capacity to generate material wealth seems to more than justify the economic power it has come to hold, these economic benefits cannot justify or legitimate the social power and impact of the company. To that extent, the privatisation of Australian company law exposes a significant democratic deficit and the issue of how that deficit is to be accounted for is, arguably, the most significant challenge facing company law.

17 The rise and extent of this power is described more fully in Grantham, above n 16.

18 N Richards and J King, 'Three Paradoxes of Big Data' (2013) 66 Stanford Law Review Online 41, 43-44.

19 The proposed European Union General Data Protection Regulation would allow an individual to request their erasure from metadata held by companies such as Google: European Commission, 'Agreement on Commission's EU Data Protection Reform Will Boost Digital Single Market', Press Release, 15 December 2015 (IP/15/6321). 


\section{Conclusion}

In its fundamentals, the Corporations Act embodies a model that was created in 1844 . That model is now overlaid with decades of amendments that reflect the ebb and flow of socioeconomic policy from laissez-faire to interventionist, and the knee-jerk reactions to a succession of scandals. The Corporations Act has thus been built up through an accretion of ideas and events whose features continue to cast a confusing shadow long after those ideas were discarded and we have forgotten the events which gave rise to them. As a practical guide and user manual for those who are actually involved in the corporate enterprise, the Act is not only wholly unsuited, but its complexity, prolixity and incoherence represent the single largest obstacle to addressing the central issues facing companies and company law in the coming decades. 
This text is taken from New Directions for Law in Australia: Essays in Contemporary Law Reform, edited by Ron Levy, Molly O’Brien, Simon Rice, Pauline Ridge and Margaret Thornton, published 2017 by ANU Press, The Australian National University, Canberra, Australia. 